RESERCH NOTE

\section{Reproductive Behavior of Ravinia belforti (Prado \& Fonseca,1932) (Diptera: Sarcophagidae) Females Reared, in Isolation, in the Laboratory at Rio de Janeiro, RJ, Brazil}

\section{José Mario d’Almeida}

Laboratório de Biologia e Controle de Insetos Vetores, Departamento de Biologia, Instituto Oswaldo Cruz, Av. Brasil 4365, 21045-900 Rio de Janeiro, RJ, Brasil

Key words: Ravinia belforti - reproductive behavior isolated females

Ravinia belforti (Prado \& Fonseca, 1932) is a sarcophagid fly of Neotropical distribution: Argentina, Brazil, Colombia, Trinidad and Paraguay (HS Lopes 1969 A catalogue of the Diptera of the Americas South of the United States, Dept ${ }^{\mathrm{O}}$ Zool Sec Agric São Paulo 88 pp). In Brazil, it is often captured in environments inhabited by man, thus presenting a high degree of synantropy (AX Linhares 1981 Rev Bras Entomol 25: 189-215, JM d'Almeida 1984 Arq Univ Fed Rur Rio de J 7: 101-110, ES Dias et al. 1984 Mem Inst Oswaldo Cruz 79: 83-91). Human and animal faeces are the most sought substrate, both as baits or as a basis for larviposition by this sarcophagid (Linhares loc. cit., d'Almeida loc. cit., HS Lopes 1973 An Acad Brasil Ci 45: 279-291).

The synanthropic habits of $R$. belforti, and its attraction for faeces, makes this sarcophagid a potential vector of human and animal entero-pathogenic microorganisms. Despite its public health importance there are no studies on its reproduction, other studies are related, as pointed above, to synanthropy and taxonomy (HS Lopes 1968 Rev Brasil Biol 28: 295-301, HS Lopes, ACR Leite1987 Mem Inst Oswaldo Cruz 82: 219-226).

The aim of the present paper was to evaluate the individual reproductive behavior of $R$. belfort $i$ females. The biological parameters, evaluated were: pre-larviposition and larviposition periods, number of larvae per larviposition and number of

Received 3 May 1995

Accepted 18 October 1995 larvipositant females, female longevity and reproductive potential (determined by the mean number of larvae per larviposition and the mean number of ovarioles presented by the females). For this last calculation, 45 females were dissected ( $15 \mathrm{fe}$ males from each essay).

Colonies of $R$. belforti were estabilished from adults captured in the Zoological Garden and on the campus of Instituto Oswaldo Cruz, both in Rio de Janeiro.

The collected flies were maintained in nylon screened wooden cages $(30 \mathrm{~cm} \mathrm{x} 30 \mathrm{~cm})$ and fed with a mixture of refined sugar, powdered milk and yeast $(2: 2: 1)$, besides a few slices of raw liver and water ad libitum, changed daily. Fresh human faeces were used as breeding substrate.

Three essays were performed, the first with 26 females from the 8th generation and the others with 25 from the 11th and 23 from the 13th generations, under environmental conditions $\left(22-28^{\circ} \mathrm{C}\right.$, $80 \pm 10 \%$ UR) at our Laboratory.

In order to start the assays, the newly emerged pairs $(1 \mathrm{~F}: 1 \mathrm{M})$ were placed in individual cages $(20 \mathrm{~cm} \times 20 \mathrm{~cm})$, and the rest used to maintain the colony. Three days after emergence, the liver slices were taken out, being replaced by human faeces as a larviposition substrate. The faeces were kept in polyethylene containers ( $4 \mathrm{~cm}$ high $\times 5 \mathrm{~cm}$ width), changed daily and left exposed for $24 \mathrm{hr}$ in the cages; after this period, the containers were taken and larvae counted.

From the $74 R$. belforti females studied, only 54 larviposited (77.3\%). MV Ferraz 1992 (Mem Inst Oswaldo Cruz 87: 131-139) recorded 100\% larviposition among females of Peckia chrysostoma and Adiscochaeta ingens (Diptera: Sarcophagidae) showing therefore a high degree of fertility and suitability of these species to laboratory conditions. These sarcophagids showed preference for decomposed meat, unlike $R$. belforti which is essentially coprophilic.

The pre-larviposition period of $R$. belforti ranged from 7 to 22 days, with an average of 12.8 days (Table I). Usually, caliptrate Diptera develop a relatively short gonadotrophic cycle, due to presence of politrophic ovaries: Phaenicia cuprina $(\overline{\mathrm{X}}=$ 4 days), Cochliomyia hominivorax $(\bar{X}=6.3$ days $)$ and Chrysomya megacephala ( $\mathrm{X}=8.02$ days) ( $\mathrm{AX}$ Linhares 1988 Rev Bras Entomol 32: 383-392).

Peak larvipositions occurred on the 14th and the 29th day after emergence. In P. chrysostoma and $A$. ingens, these peaks of larviposition were between the 34th and the 36th and at the 24th day of life, respectively (Ferraz 1992 loc. cit).

Reproductive potential of $R$. belforti females is shown in Table II, as well as, the mean number of ovarioles per ovary. The number of functioning 
TABLE I

Values of the various biological parameters of Ravinia belforti maintained under laboratory contitions, in Rio de Janeiro

\begin{tabular}{lccccc}
\hline \multirow{2}{*}{ Parameters } & \multicolumn{5}{c}{ Values } \\
\cline { 2 - 6 } & $\min$ & $\max$ & mean & SD & $\%$ SD \\
\hline Pre-larviposition period (in days) & 7 & 22 & 12.8 & 3.89 & 30.4 \\
Larviposition period (in days) & 1 & 55 & 17.14 & 13.8 & 80.7 \\
Number of larvipositions & 1 & 14 & 4.7 & 3.3 & 70.03 \\
Mean number of larvae per larviposition & 2.2 & 19 & 11.5 & 4.04 & 35.13 \\
Mean number of larvae per females & 5 & 163 & 56.1 & 46.26 & 82.47 \\
Logevity of females & 6 & 69 & 34.2 & 20.9 & 61.1 \\
\hline
\end{tabular}

min: minimum; max: maximum; SD: standard deviation; \%SD: \% standard deviation

\section{TABLE II}

Comparison among the number of ovirioles and reproductive potential of Ravinia belfort, under laboratory conditions, in Rio de Janeiro

\begin{tabular}{clll}
\hline \multicolumn{4}{c}{ Variables } \\
\hline $\mathrm{a}$ & $\mathrm{b}$ & $\mathrm{c}$ & $\mathrm{RP}(\%)$ \\
\hline
\end{tabular}

$13.2 \pm 2.6 \quad 26.4 \pm 5.1 \quad 11.5 \pm 4.04 \quad 43.56$

a: mean ovirioles per avary; b: mean ovirioles per females; c: mean number of larvae per larviposition; $\mathrm{RP}(\%)$ : reproductive potential

ovarioles present in the flies ovaries is widely variable, according to the species. The feeding and environmental conditions (Ferraz 1992 loc.cit), varying due to the number of gonadotrophic cycles (JR Anderson 1964 Ann Entomol Soc Am 57: 226236). $R$. belforti presented a low reproductive potential $(43.56 \%)$ when compared with the sarcophagids $P$. chrysostoma $(63.3 \%)$ and $A$. ingens (55.5\%) already considered low by the author (Ferraz 1992 loc cit).

Preliminary observation on the behavior of $R$. belforti, as related to the factors studied showed that this specie had a low reproductive potential, when compared to others Neotropical sarcophagids, that are not coprophilic. Thus, it is necessary to compare these results to coprophilic sarcophagids, to evaluate if this low reproductive potential is a characteristic of $R$. belforti or if it is a peculiarity of coprophilic sarcophagids. 